\title{
MENGUPAS MOTIF \& KEPUASAN PENGGUNA BLACKBERRY DI INDONESIA
}

\author{
Handy Martinus \\ Jurusan Marketing Communication, Fakultas Komunikasi dan Multimedia, Bina Nusantara University \\ Jln. K.H. Syahdan No. 9, Kemanggisan, Palmerah, Jakarta Barat 11480
}

\begin{abstract}
Lately, BlackBerry is familiar in many people, especially due to the publicity of problems between Indonesia's communication and information ministry and Canada-based BlackBerry developer, Research in Motion (RIM). In doing the research, the writer spread pre-questionnaire to 30 respondents to validity and reliability test. Afterwards, the writer gave the questionnaires to 100 respondents as BlackBerry users in employees' limitation. The result is that there is satisfaction towards information, private identity, integration, and social interaction, and also towards entertainment after using BlackBerry.
\end{abstract}

Keywords: BlackBerry, information, private identity, integration, social interaction, entertainment

\begin{abstract}
ABSTRAK
Akhir-akhir ini BlackBerry semakin familiar di berbagai kalangan, terutama dengan diperkuatnya dengan pemberitaan permasalahan antara Kementrian Komunikasi dan Informasi Republik Indonesia dengan pengembang BlackBerry yang berpusat di Kanada yakni Research in Motions (RIM). Dalam melakukan penelitian, penulis menyebarkan pra-kuesioner pada 30 responden untuk dilakukan uji Validitas dan Reliabilitas. Setelah itu penulis menyebarkan kuesioner pada 100 orang responden yang merupakan pengguna BlackBerry dengan batasan usia pekerja kantor. Hasil yang didapat yaitu bahwa terdapat kepuasan terhadap informasi, identitas pribadi, integrasi dan interaksi sosial, serta terhadap hiburan setelah menggunakan BlackBerry.
\end{abstract}

Kata kunci: BlackBerry, informasi, identitas pribadi, integrasi, interaksi sosial, hiburan 


\section{PENDAHULUAN}

Akhir-akhir ini BlackBerry semakin familiar diberbagai kalangan, terutama dengan diperkuatnya dengan pemberitaan permasalahan antara Kementrian Komunikasi dan Informasi Republik Indonesia dengan pengembang BlackBerry yang berpusat di Kanada yakni Research in Motions (RIM). BlackBerry merupakan perangkat genggam nirkabel yang memiliki kemampuan layanan push e-mail, telepon seluler, sms, mms, internet browser dan berbagai kemampuan lainnya. Didirikan oleh seorang imigran Yunani di kota Waterlo, Kanada. Pendiri RIM, Mike Lazaridis dilahirkan di Turki dan berkuliah di Universitas Waterloo. Dia memilih untuk Drop-out setelah memenangkan kontrak senilai U\$560,000. Para pesimis mengasumsikan bahwa pesaing besar akan menenggelamkan produk BlackBerry dengan membanjiri pasar dengan produk yang serupa. Namun hingga saat ini, belum ada satu perusahaan pun seperti Nokia, Motorola, Sony Ericsson ataupun Microsoft yang mampu mengoyang posisi BlackBerry di Indonesia.

BlackBerry pertama kali diperkenalkan di Indonesia pada pertengahan Desember 2004 oleh operator Indosat dan perusahan Starhub (Abe, 2011). Di Indonesia, Starhub menjadi bagian dari layanan dalam segala hal teknis mengenai instalasi BlackBerry melalui operator Indosat. Indosat menyediakan layanan BlackBerry Internet Service (BIS) dan BlackBerry Enterprise Service (BES).

Kelebihan lainnya adalah kemampuan BlackBerry yang dapat menampung e-mail yang sudah dikompress oleh server RIM hingga puluhan ribu tanpa ada resiko hang, selama memiliki memory yang mencukupi. Fitur andalan yang sangat digemari dari BlackBerry adalah yang biasa digunakan unutk chating atau lebih dikenal dengan BlackBerry Messenger (BBM) yang dilakukan melalui jaringan BlackBerry dengan memasukan nomor indentitas (PIN) dari BlackBerry tersebut.

Yang menarik dari BlackBerry adalah begitu fenomenalnya menggeser posisi Nokia yang selalu berada di puncak pangsa pasar. Bahkan timbul istilah pengguna BlackBerry yang disebut autis karena begitu asyiknya hingga menjauhkan orang yang berada di dekatnya. Untuk itu dalam tulisan ini berusaha mengupas berbagai motif dan kepuasan yang diperoleh pengguna BlackBerry dengan berpedoman pada teori uses and gratification (McQuail, 1987).

\section{Tujuan Penelitian}

Tujuan penelitian dapat diartikan sebagai target pencapaian akhir yang akan diperoleh, dan sekaligus sebagai rangkaian tahap pencapaian target secara keseluruhan. Tujuan penelitian ini: (1) untuk mengetahui kepuasan informasi yang diperoleh pengguna BlackBerry; (2) untuk mengetahui kepuasan identitas pribadi yang diperoleh pengguna BlackBerry; (3) untuk mengetahui kepuasan integrasi dan interaksi sosial yang diperoleh pengguna BlackBerry; (4) untuk mengetahui kepuasan hiburan yang diperoleh pengguna BlackBerry.

\section{Batasan Penelitian}

Dalam melakukan penelitian, penulis menyebarkan pra-kuesioner pada 30 responden untuk dilakukan uji Validitas dan Reliabilitas. Setelah itu penulis menyebarkan kuesioner pada 100 orang responden yang merupakan pengguna BlackBerry dengan batasan usia pekerja kantor.

\section{Kerangka Pemikiran}

Kerangka pemikiran yang digunakan dalam penelitian ini adalah menggunakan dasar dari teori uses \& gratification yang dikembangkan oleh McQuail (1987). 


\section{Gratification Sought \& Gratification Obtained}

Setiap orang memerlukan informasi yang cepat dan akurat. Dengan adanya internet, kebutuhan akan informasi dapat terpenuhi. Internet menjadi suatu media baru yang up to date,menyediakan informasi yang lengkap, mulai dari informasi tentang berita,hiburan,akses email,sampai situs jejaring sosial,seperti: facebook,twitter, dan lainlain.Keunggulan internet bisa diakses kapanpun dan di mana pun.

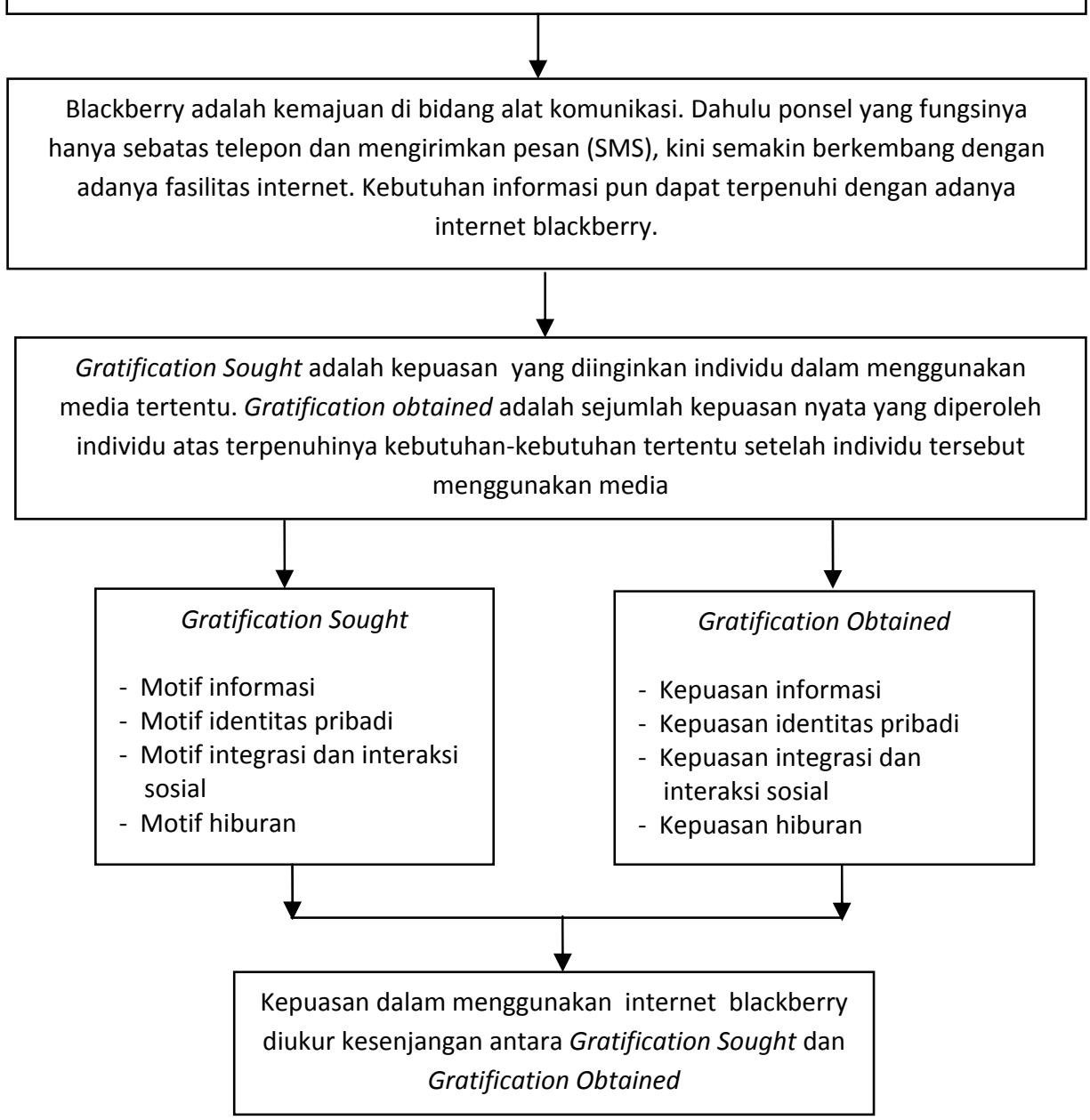

HASIL DAN PEMBAHASAN

\section{Pengolahan Data}

\section{Uji Validitas}

Penulis melakukan uji validitas kepada kuesioner yang telah disebarkan kepada 30 responden tersebut, untuk mengetahui apakah ada pertanyaan-pertanyaan pada kuesioner yang harus dibuang atau diganti karena dianggap tidak relevan. Pengujiannya dilakukan secara statistik, dengan dibantu dukungan software SPSS. Dari 17 pertanyaan yang diukur, ternyata tidak ada pertanyaan yang tidak valid. Hasil itu dilihat dari hasil perhitungan SPSS. Berdasarkan $\mathrm{r}$-tabel product moment, untuk $\mathrm{n}=30$, $r>0,361$ dengan interval kepercayaan $95 \%$ atau $\alpha=5 \%$. Hasil perhitungan validitas dapat dilihat pada tabel berikut ini. 
Tabel 1 Hasil Uji Validitas Motif Informasi

\begin{tabular}{clc}
\hline No & \multicolumn{1}{c}{ Pertanyaan } & Keterangan \\
\hline 1 & $\begin{array}{l}\text { Saya ingin mendapatkan informasi mengenai berbagai peristiwa dan } \\
\text { kondisi yang berkaitan dengan lingkungan sekitar } \\
\text { Saya ingin mendapatkan semua info, dalam BlackBerry mengenai } \\
\text { berbagai peristiwa dan kondisi yang berkaitan dengan keadaan } \\
\text { dunia saat ini seperti situasi politik, ekonomi, dan sosial budaya }\end{array}$ & Valid \\
3 & $\begin{array}{l}\text { Saya ingin mendapatkan pengetahuan akan solusi untuk berbagai } \\
\text { masalah, mulai dari masalah lalu lintas sampai masalah mata } \\
\text { pekerjaan }\end{array}$ & Valid \\
4 & $\begin{array}{l}\text { Saya ingin mendapatkan banyak pengetahuan baru dari broadcast } \\
\text { BlackBerry messenger (BBM), seperti info seputar BlackBerry. } \\
\text { Saya ingin dapat memuaskan rasa keingintahuan mengenai } \\
\text { informasi-informasi baru masa kini. }\end{array}$ & Valid \\
\hline
\end{tabular}

Tabel 2 Hasil Uji Validitas Dimensi Motif Identitas Pribadi

\begin{tabular}{clc}
\hline No & \multicolumn{1}{c}{ Pertanyaan } & Keterangan \\
\hline 6 & $\begin{array}{l}\text { Saya ingin dapat menemukan nilai-nilai penunjang seperti saya dianggap } \\
\text { up-to-date, saya dianggap keren atau hal-hal lain yang berkaitan dengan } \\
\text { diri saya. }\end{array}$ & Valid \\
7 & $\begin{array}{l}\text { Saya ingin dapat menambah rasa percaya diri saya setelah menggunakan } \\
\text { BlackBerry. }\end{array}$ & Valid \\
8 & $\begin{array}{l}\text { Saya ingin mendapatkan pengetahuan akan hal-hal yang berkaitan } \\
\text { dengan gaya hidup atau cara hidup yang baik }\end{array}$ & Valid \\
\hline
\end{tabular}

Tabel 3 Hasil Uji Validitas Dimensi Motif Integrasi dan Interaksi Sosial

\begin{tabular}{clc}
\hline No & \multicolumn{1}{c}{ Pertanyaan } & Keterangan \\
\hline 9 & $\begin{array}{l}\text { Saya ingin lebih dipandang oleh orang lain setelah menggunakan } \\
\text { BlackBerry, karena banyaknya pengetahuan yang saya dapat. }\end{array}$ & Valid \\
10 & $\begin{array}{l}\text { Saya ingin lebih mudah berinteraksi dengan orang lain sejak } \\
\text { menggunakan BlackBerry. }\end{array}$ & Valid \\
11 & $\begin{array}{l}\text { Saya ingin dapat berperan aktif dalam kegiatan komunitas tertentu karena } \\
\text { lebih mudah saya bergaul setelah menggunakan BlackBerry } \\
\text { Saya ingin lebih dekat dengan orang lain setelah menggunakan }\end{array}$ & Valid \\
12 & $\begin{array}{l}\text { BlackBerry } \\
\text { Saya ingin dapat lebih dihargai oleh orang lain karena saya lebih up to } \\
\text { date karena menggunakan BlackBerry }\end{array}$ & Valid \\
\hline
\end{tabular}

Tabel 4 Hasil Uji Validitas Dimensi Motif Hiburan

\begin{tabular}{clc}
\hline No & \multicolumn{1}{c}{ Pertanyaan } & \multicolumn{1}{c}{ Keterangan } \\
\hline 14 & $\begin{array}{l}\text { Saya ingin dapat mengatasi rasa bosan setelah menggunakan } \\
\text { BlackBerry }\end{array}$ & Valid \\
15 & $\begin{array}{l}\text { Saya ingin dapat megisi waktu luang saya setelah menggunakan } \\
\text { BlackBerry }\end{array}$ & Valid \\
16 & $\begin{array}{l}\text { Saya ingin dapat mengatasi saya kesepian setelah menggunakan } \\
\text { BlackBerry. } \\
\text { Saya ingin mendapatkan hiburan dan kesenangan setelah } \\
\text { menggunakan BlackBerry }\end{array}$ & Valid \\
\hline
\end{tabular}




\section{Uji Reliabilitas}

Dari 17 pertanyaan tersebut kemudian diuji Reliabilitasnya. Reliabilitas merujuk pada adanya konsistensi dan stabilitas nilai hasil pengukuran skala pengukuran tertentu. Uji Reliabilitas berguna untuk menetapkan apakah instrument pertanyaan pada kuesioner dapat stabil atau sama, dapat digunakan lebih dari satu kali. Dalam artian responden akan mengisi jawaban yang sama atau tidak berubah seandainya dimintakan untuk mengisi dan mengisi lagi. Uji Reliabilitas menggunakan program SPSS dengan metode conbarch alpha $\geq 0,7$. Didapat hasil bahwa nilai Reliabilitas tiap variabel pertanyaannya yaitu variabel $1(0,950)$, varibel $2(0,956)$, variabel $3(0,909)$, variabel 4 $(0,964)$. Oleh karena itu semua variabel dinyatakan reliable. Hasil perhitungan Reliabilitas dapat dilihat pada tabel 5 .

Tabel 5 Hasil Uji Reliabilitas

\begin{tabular}{lcc}
\hline \multicolumn{1}{c}{ Dimensi } & Nilai Alpha & Keterangan \\
\hline Motif Informasi & 0,950 & Reliable \\
Motif Identitas Pribadi & 0,956 & Reliable \\
Motif Integrasi dan Interaksi Sosial & 0,909 & Reliable \\
Motif Hiburan & 0,964 & Reliable \\
\hline
\end{tabular}

\section{Analisis Demografi}

Hasil penyebaran kuesioner dapat dilihat pada jenis kelamin dan tingkat usia responden seperti pada tabel berikut ini.

Tabel 6 Jenis Kelamin Responden

\begin{tabular}{ccc}
\hline Jenis Kelamin & Responden & Persentase \\
\hline Pria & 35 & 35 \\
Wanita & 65 & 65 \\
TOTAL & 100 & 100 \\
\hline
\end{tabular}

Tabel 7 Tingkat Usia Responden

\begin{tabular}{ccc}
\hline Tingkat Usia & Responden & Persentase \\
\hline$\leq 20$ tahun & 11 & 11 \\
$21-30$ tahun & 59 & 59 \\
$31-40$ tahun & 28 & 28 \\
$\geq 41$ tahun & 2 & 2 \\
TOTAL & 100 & 100 \\
\hline
\end{tabular}

\section{Analisis Motif dan Kepuasan}

\section{Motif (Gratification Sought)}

Penjelasan yang dipaparkan pada tabel 8 , bahwa hasil pengolahan data kuesioner pada Gratification Sought, didapat bahwa hasil dari rata-rata motif informasi adalah sebesar 3,91 responden setuju ingin mendapatkan informasi setelah menggunakan BlackBerry. Dalam skala Likert digambarkan:

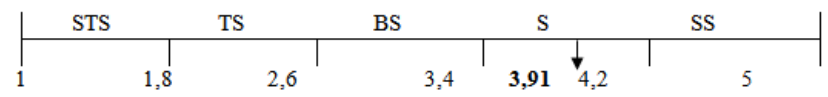


Penjelasan yang dipaparkan pada tabel 4.9, bahwa hasil pengolahan data kuesioner pada Gratification Sought, didapat bahwa hasil dari rata-rata motif identitas pribadi adalah sebesar 3,96 orang responden setuju ingin mendapatkan identitas pribadi setelah menggunakan BlackBerry. Dalam skala Likert digambarkan:

\begin{tabular}{|c|c|c|c|c|}
\hline STS & TS & BS & $S$ & SS \\
\hline 1,8 & & & $3,964,2$ & \\
\hline
\end{tabular}

Penjelasan yang dipaparkan pada tabel 4.9, bahwa hasil pengolahan data kuesioner pada Gratification Sought, didapat bahwa hasil dari rata-rata motif integrasi dan interaksi adalah sebesar 3,90 orang responden ingin mendapatkan integrasi dan interaksi setelah menggunakan BlackBerry. Dalam skala Likert digambarkan:

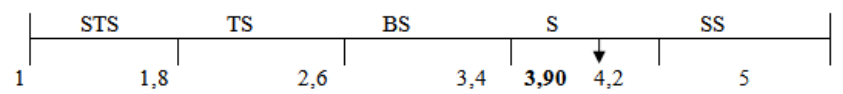

Penjelasan yang dipaparkan pada tabel 4.9, bahwa hasil pengolahan data kuesioner pada Gratification Sought, didapat bahwa hasil dari rata-rata motif hiburan sosial adalah sebesar 3,93 orang responden setuju menginginkan untuk mendapatkan hiburan setelah menggunakan BlackBerry. Dalam skala Likert digambarkan:

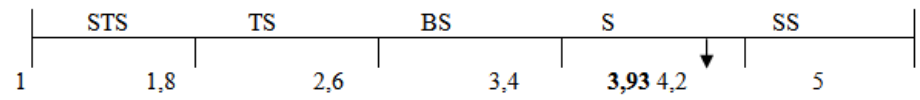

Tabel 8 Gratification Sought

\begin{tabular}{|c|c|c|c|c|c|c|}
\hline STS & TS & N & S & SS & N & Rata- \\
1 & 2 & 3 & 4 & 5 & & Rata \\
\hline
\end{tabular}

\section{Informasi}

Ingin mendapatkan informasi mengenai berbagai peristiwa dan kondisi yang berkaitan dengan lingkungan sekitar Ingin mendapatkan semua info, dalam blackbery mengenai berbagai peristiwa dan kondisi yang berkaitan dengan keadaan dunia saat ini seperti situasi politik, ekonomi, dan sosial budaya

Ingin mendapatkan pengetahuan akan solusi untuk berbagai masalah, mulai dari masalah lalu lintas sampai masalah mata kuliah

Ingin mendapatkan banyak pengetahuan baru dari broadcast

BlackBerry messenger (BBM), seperti info seputar BlackBerry

Ingin dapat memuaskan rasa keingintahuan mengenai informasi-informasi baru masa kini

$\begin{array}{lllllll}0 & 10 & 22 & 15 & 53 & 100 & 4.11 \\ 0 & 14 & 30 & 20 & 36 & 100 & 3.78\end{array}$

\section{Identitas Pribadi}

Ingin menemukan nilai-nilai penunjang seperti saya dianggap up to date, saya dianggap keren atau hal-hal lain yang berkaitan dengan diri saya.

Ingin dapat menambah rasa percaya diri saya setelah menggunakan BlackBerry.

Ingin mendapatkan Pengetahuan akan hal-hal yang berkaitan dengan gaya hidup atau cara hidup yang baik

$\begin{array}{lllllll}0 & 15 & 31 & 7 & 47 & 100 & 3.86 \\ 0 & 6 & 34 & 22 & 38 & 100 & 3.92 \\ 0 & 12 & 32 & 12 & 44 & 100 & 3.88 \\ 0 & 10 & 31 & 19 & 40 & 100 & 3.89 \\ 0 & 8 & 27 & 18 & 47 & 100 & 4.04 \\ 0 & 9 & 31 & 15 & 45 & 100 & 3.96\end{array}$




\begin{tabular}{|c|c|c|c|c|c|c|c|}
\hline & STS & TS & $\mathrm{N}$ & $\mathrm{S}$ & SS & $\mathrm{N}$ & $\begin{array}{l}\text { Rata- } \\
\text { Rata }\end{array}$ \\
\hline \multicolumn{8}{|l|}{ 3. Integrasi dan Interaksi Sosial } \\
\hline $\begin{array}{l}\text { Ingin lebih dipandang oleh orang lain setelah menggunakan } \\
\text { BlackBerry, karena banyaknya pengetahuan yang saya dapat. }\end{array}$ & 0 & 11 & 31 & 15 & 43 & 100 & 3.90 \\
\hline $\begin{array}{l}\text { Ingin dengan mudah berinteraksi dengan orang lain sejak } \\
\text { menggunakan BlackBerry. }\end{array}$ & 0 & 8 & 29 & 15 & 48 & 100 & 4.03 \\
\hline $\begin{array}{l}\text { Ingin berperan aktif dalam kegiatan komunitas tertentu } \\
\text { karena lebih mudah saya bergaul setelah menggunakan } \\
\text { BlackBerry }\end{array}$ & 1 & 8 & 39 & 18 & 34 & 100 & 3.76 \\
\hline $\begin{array}{l}\text { Ingin lebih dekat dengan orang lain setelah menggunakan } \\
\text { BlackBerry. }\end{array}$ & 0 & 5 & 35 & 21 & 39 & 100 & 3.94 \\
\hline $\begin{array}{l}\text { Ingin lebih dihargai oleh orang lain karena saya lebih up to } \\
\text { date karena menggunakan BlackBerry }\end{array}$ & 0 & 10 & 38 & 9 & 43 & 100 & 3.85 \\
\hline \multicolumn{8}{|l|}{ 4. Hiburan } \\
\hline Ingin mengatasi rasa bosan setelah menggunakan BlackBerry & 0 & 11 & 29 & 19 & 41 & 100 & 3.90 \\
\hline $\begin{array}{l}\text { Ingin mengisi waktu luang saya setelah menggunakan } \\
\text { BlackBerry }\end{array}$ & 0 & 12 & 29 & 14 & 45 & 100 & 3.92 \\
\hline $\begin{array}{l}\text { Ingin dapat mengatasi saya kesepian setelah menggunakan } \\
\text { BlackBerry. }\end{array}$ & 0 & 11 & 28 & 19 & 42 & 100 & 3.92 \\
\hline $\begin{array}{l}\text { Ingin mendapatkan hiburan dan kesenangan setelah } \\
\text { menggunakan BlackBerry }\end{array}$ & 1 & 8 & 28 & 17 & 46 & 100 & 3.99 \\
\hline
\end{tabular}

\section{Kepuasan (Gratification Obtained)}

Penjelasan yang dipaparkan pada tabel 9, bahwa hasil olah data kuesioner pada Gratification Obtained sebesar 3,89. Hal ini menunjukkan, responden setuju terhadap kepuasan informasi yang didapat setelah menggunakan BlackBerry.

Penjelasan yang dipaparkan pada tabel 10, bahwa hasil olah data kuesioner pada Gratification Obtained sebesar 3.83. Hal ini menunjukkan, responden setuju terhadap kepuasan identitas pribadi yang didapat setelah menggunakan BlackBerry.

Penjelasan yang dipaparkan pada tabel 10, bahwa hasil olah data kuesioner pada Gratification Obtained sebesar 3,96. Hal ini menunjukkan, responden setuju terhadap kepuasan integrasi dan interaksi sosial yang diperoleh setelah yang didapat setelah menggunakan BlackBerry

Penjelasan yang dipaparkan pada tabel 10, bahwa hasil olah data kuesioner pada Gratification Obtained sebesar 3.93. Hal ini menunjukkan, responden setuju terhadap kepuasan hiburan yang didapat setelah menggunakan BlackBerry. 
Tabel 9 Gratification Obtained

\begin{tabular}{|c|c|c|c|c|c|c|c|}
\hline & $\begin{array}{c}\text { STS } \\
1 \\
\end{array}$ & $\begin{array}{c}\text { TS } \\
2 \\
\end{array}$ & $\begin{array}{l}\mathrm{N} \\
3 \\
\end{array}$ & $\begin{array}{l}S \\
4\end{array}$ & $\begin{array}{c}\text { SS } \\
5 \\
\end{array}$ & $\mathrm{~N}$ & Rata-Rata \\
\hline \multicolumn{8}{|l|}{ 1. Informasi } \\
\hline $\begin{array}{l}\text { Mendapatkan informasi mengenai berbagai peristiwa dan } \\
\text { kondisi yang berkaitan dengan lingkungan sekitar }\end{array}$ & 1 & 10 & 27 & 19 & 43 & 100 & 3.93 \\
\hline $\begin{array}{l}\text { Mendapatkan semua info, dalam BlackBerry mengenai } \\
\text { berbagai peristiwa dan kondisi yang berkaitan dengan } \\
\text { keadaan dunia saat ini seperti situasi politik, ekonomi, } \\
\text { dan sosial budaya }\end{array}$ & 1 & 9 & 34 & 14 & 42 & 100 & 3.87 \\
\hline $\begin{array}{l}\text { Mendapatkan pengetahuan akan solusi untuk berbagai } \\
\text { masalah, mulai dari masalah lalu lintas sampai masalah } \\
\text { mata kuliah }\end{array}$ & 0 & 11 & 33 & 14 & 42 & 100 & 3.87 \\
\hline Mendapatkan banyak pengetahuan baru dari broadcast & & & & & & & \\
\hline $\begin{array}{l}\text { BlackBerry messenger (BBM), seperti info seputar } \\
\text { BlackBerry. }\end{array}$ & 0 & 12 & 31 & 11 & 46 & 100 & 3.91 \\
\hline $\begin{array}{l}\text { Dapat memuaskan rasa keingintahuan mengenai } \\
\text { informasi-informasi baru masa kini. }\end{array}$ & 1 & 8 & 34 & 15 & 42 & 100 & 3.89 \\
\hline \multicolumn{8}{|l|}{ 2. Identitas Pribadi } \\
\hline $\begin{array}{l}\text { Dapat menemukan nilai-nilai penunjang seperti saya } \\
\text { dianggap ud to date, saya dianggap keren atau hal-hal lain } \\
\text { yang berkaitan dengan diri saya. }\end{array}$ & 1 & 11 & 33 & 16 & 39 & 100 & 3.81 \\
\hline $\begin{array}{l}\text { Dapat menambah rasa percaya diri saya setelah } \\
\text { menggunakan BlackBerry. }\end{array}$ & 2 & 5 & 35 & 17 & 41 & 100 & 3.90 \\
\hline $\begin{array}{l}\text { Mendapatkan pengetahuan akan hal-hal yang berkaitan } \\
\text { dengan gaya hidup atau cara hidup yang baik }\end{array}$ & 1 & 8 & 39 & 17 & 35 & 100 & 3.77 \\
\hline \multicolumn{8}{|l|}{ 3. Integrasi dan Interaksi Sosial } \\
\hline $\begin{array}{l}\text { BlackBerry, karena banyaknya pengetahuan yang saya } \\
\text { dapat. }\end{array}$ & 0 & 9 & 26 & 19 & 46 & 100 & 4.02 \\
\hline $\begin{array}{l}\text { Sangat mudah berinteraksi dengan orang lain sejak } \\
\text { menggunakan BlackBerry. }\end{array}$ & 0 & 11 & 26 & 15 & 48 & 100 & 4.00 \\
\hline $\begin{array}{l}\text { Dapat berperan aktif dalam kegiatan komunitas tertentu } \\
\text { karena lebih mudah saya bergaul setelah menggunakan } \\
\text { BlackBerry }\end{array}$ & 0 & 11 & 27 & 20 & 42 & 100 & 3.93 \\
\hline $\begin{array}{l}\text { Lebih dekat dengan orang lain setelah menggunakan } \\
\text { BlackBerry }\end{array}$ & 0 & 11 & 32 & 15 & 42 & 100 & 3.88 \\
\hline $\begin{array}{l}\text { Dapat lebih dihargai oleh orang lain karena saya lebih up } \\
\text { to date karena menggunakan BlackBerry }\end{array}$ & 0 & 8 & 31 & 16 & 45 & 100 & 3.98 \\
\hline \multicolumn{8}{|l|}{ 4. Hiburan } \\
\hline $\begin{array}{l}\text { Dapat mengatasi rasa bosan setelah menggunakan } \\
\text { BlackBerry }\end{array}$ & 0 & 13 & 26 & 18 & 43 & 100 & 3.91 \\
\hline $\begin{array}{l}\text { Dapat megisi waktu luang saya setelah menggunakan } \\
\text { BlackBerry }\end{array}$ & 0 & 8 & 31 & 14 & 47 & 100 & 4.00 \\
\hline $\begin{array}{l}\text { Dapat mengatasi saya kesepian setelah menggunakan } \\
\text { BlackBerry. }\end{array}$ & 0 & 10 & 29 & 23 & 38 & 100 & 3.89 \\
\hline $\begin{array}{l}\text { Mendapatkan hiburan dan kesenangan setelah } \\
\text { menggunakan BlackBerry }\end{array}$ & 0 & 7 & 35 & 16 & 42 & 100 & 3.93 \\
\hline
\end{tabular}

\section{Uji Normalitas Data}

Data dikatakan berdistribusi normal jika nilai sig-nya $\geq 0,05$ atau sebaliknya jika nilai sig-nya $<0,05$ data dikatakan tidak berdistribusi normal. Jika data berdistribusi normal maka dilakukan pengujian parametrik yaitu Paired T.Test. sebaliknya bila tidak berdistribusi normal menggunakan pengujian nonparametric Wilcoxon. 
Ho: data berdistribusi normal

Ha: data berdistribusi tidak normal maka

Pengujian pada motif informasi, identitas pribadi, integrasi \& interaksi sosial dan hiburan dengan menggunakan kolmogorov smirnov, didapat data seperti pada tabel 10. Gratification Sought motif informasi, integrasi \& interaksi sosial dan hiburan berdistribusi normal (nilai asymp sig. $\geq 0,05$ ) dan Gratification Obtained motif informasi, integrasi \& interaksi sosial dan hiburan juga berdistribusi normal. Karena data tersebut berdistribusi normal maka pengujian perbedaan rata-rata Gratification Sought dengan Gratification Obtained motif informasi, integrasi \& interaksi sosial dan hiburan diuji dengan menggunakan Paired T-Test.

Sedangkan untuk pengujian pada motif identitas pribadi, didapat data seperti pada tabel 11 . Gratification Sought tidak berdistribusi normal (nilai asymp sig. $<0,05$ ) dan Gratification Obtained identitas pribadi berdistribusi normal. Maka pengujian perbedaan rata-rata Gratification Sought dengan Gratification Obtained identitas pribadi diuji dengan menggunakan Wilcoxon.

Tabel 10 Uji Normalitas Data

\begin{tabular}{ccc}
\hline \multirow{2}{*}{ Motif } & \multicolumn{2}{c}{ Asymp sig. ( 2 tailed ) } \\
\cline { 2 - 3 } & Sought & Obtained \\
\hline Informasi & 0,066 & 0,318 \\
\hline Identitas Pribadi & 0,034 & 0,139 \\
\hline Integrasi dan Interaksi Sosial & 0,142 & 0,170 \\
\hline Hiburan & 0,165 & 0,263 \\
\hline
\end{tabular}

\section{Pengujian Motif dan Kepuasan}

\section{Uji Paired T-Test}

Pengujian Paired T-Test dilakukan untuk melihat apakah ada perbedaan antara Gratification Sought (Gs) dan Gratification Obtained (Go) dilihat dari aspek informasi, integrasi \& interaksi sosial dan hiburan yang berdistribusi normal.

Ho: $\mathrm{Gs}=\mathrm{Go}$

Ha: $\mathrm{Gs} \neq$ Go

Tolak Ho: bila asymp sig $<0,05$

Terima Ho: bila asymp sig $\geq 0,05$

Hasilnya ada pada Tabel 11 berikut ini.

Tabel 11 Pengujian terhadap Motif Informasi

\begin{tabular}{cccc}
\hline & Mean & T & Sig.(2-tailed) \\
\cline { 1 - 2 } S_Info & 19,55 & 0,195 & 0,846 \\
\cline { 1 - 2 } O_Info & 19,47 & & \\
\hline
\end{tabular}

Simpulan: Terima Ho yang berarti terdapat kepuasan informasi. 
Tabel 12 Pengujian terhadap Motif Integrasi dan Interaksi Sosial

\begin{tabular}{|c|c|c|c|}
\hline & Mean & $\mathrm{T}$ & Sig.(2-tailed) \\
\hline S_Integrasi & 19,48 & $-0,725$ & 0,470 \\
\hline O_Integrasi & 19,81 & & \\
\hline
\end{tabular}

Simpulan: Terima Ho yang berarti terdapat kepuasan integrasi dan interaksi sosial.

Tabel 13 Pengujian terhadap Motif Hiburan

\begin{tabular}{|c|c|c|c|}
\hline & Mean & $\mathrm{T}$ & Sig.(2-tailed) \\
\hline S_Hiburan & 15,73 & 0,000 & 1,000 \\
\hline O_Hiburan & 15,73 & & \\
\hline
\end{tabular}

Simpulan: Terima Ho yang berarti terdapat kepuasan hiburan.

\section{Uji Wilcoxon}

Pengujian Wilcoxon dilakukan untuk melihat apakah ada perbedaan antara Gratification Sought (Gs) dan Gratification Obtained (Go) dilihat dari aspek identitas pribadi yang tidak berdistribusi normal.

Ho: $\mathrm{Gs}=\mathrm{Go}$

Ha: Gs $\neq$ Go

Tolak Ho: bila asymp sig $<0,05$

Terima Ho: bila asymp sig $\geq 0,05$

Hasilnya ada pada Tabel 14 berikut ini.

Tabel 14 Pengujian terhadap Motif Identitas Pribadi

\begin{tabular}{cccc}
\hline & Mean & Z & Asymp 2 tailed \\
\hline S_Pribadi & 11,8900 & & $-1,173$ \\
O_Pribadi & 11,4800 & & 0,241 \\
\hline
\end{tabular}

Simpulan: Terima Ho yang berarti terdapat kepuasan identitas pribadi.

\section{PENUTUP}

Pengolahan data untuk pengujian Motif dan Kepuasan dengan menggunakan uji T-Paired Test dan Wilcoxon dengan program SPSS, bahwa:

\section{Motif vs Kepuasan Informasi}

Berdasarkan pengujian Paired T-Test, tidak ada perbedaan antara Gratification Sought dan Gratification Obtained pada motif informasi. Dengan kata lain, terdapat kepuasan terhadap informasi setelah menggunakan BlackBerry. 


\section{Motif vs Kepuasan Identitas Pribadi}

Melalui pengujian Wilcoxon tidak ada perbedaan antara Gratification Sought dan Gratification Obtained pada motif identitas pribadi. Dengan kata lain, terdapat kepuasan terhadap identitas pribadi setelah menggunakan BlackBerry.

\section{Motif vs Kepuasan Integrasi dan Interaksi Sosial}

Berdasarkan pengujian Paired T-Test, tidak ada perbedaan antara Gratification Sought dan Gratification Obtained pada motif integrasi dan interaksi sosial. Dengan kata lain, terdapat kepuasan terhadap integrasi dan interaksi sosial setelah menggunakan BlackBerry.

\section{Motif vs Kepuasan Hiburan}

Melalui pengujian Paired T-Test, tidak ada perbedaan antara Gratification Sought dan Gratification Obtained pada motif hiburan. Dengan kata lain, terdapat kepuasan terhadap hiburan setelah menggunakan BlackBerry.

\section{DAFTAR PUSTAKA}

Abe, B. (2008). Blackberry: Smart cell phone that has won hearts, The Jakarta Post Online. Diunduh dari http://www.thejakartapost.com/news/2008/12/16/blackberry-smart-cell-phone-has-wonhearts.html .

McQuail, D. (1987). Mass Communication Theory: An Introduction (2nd ed.). London: Sage 